Staff Paper No. 78

\title{
Fear of Appreciation in East and Southeast Asia: The Role of the Chinese Renminbi
}

Victor Pontines and Reza Y. Siregar

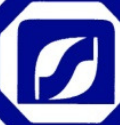

The South East Asian Central Banks (SEACEN)

Research and Training Centre

(The SEACEN Centre)

Kuala Lumpur, Malaysia 


\title{
Fear of Appreciation in East and Southeast Asia: The Role of the Chinese Renminbi*
}

\author{
Victor Pontines $^{\mathrm{a}}$ and Reza Y. Siregar
}

October 2010

a. Victor Pontines is with the Flinders Business School, Australia. E-mail: victor.pontines@ flinders.edu.au

b. Reza Y. Siregar is with the South East Asian Central Banks (SEACEN) Research and Training Centre in Kuala Lumpur, Malaysia. E-mail: reza@ seacen.org and rezasiregar@yahoo.com.

*The findings, interpretation and conclusions expressed in this study are entirely those of the authors. They do not necessarily represent the views of the SEACEN Centre, its member central banks and the Flinders Business School. 


\section{Table of Contents}

\section{Page}

Abstract

1. Introduction

2. Empirical Approach 3

3. Empirical Results

4. Recent Trends in Bilateral Trade Patterns and the Dominant Role of Mainland China

5. Conclusion

References

\section{List of Tables}

Table 1: Correlation between the Renminbi and Selected East and

Southeast Asian Currencies

Table 2: Estimation Results for Regime Switching Models of

East Asian Currencies per US\$

Table 3: Estimation Results for Regime Switching Models of

East Asian Currencies per Renminbi

Table 4: Diagnostic Test Results

Table 5: Transition Probabilities

\section{List of Figures}

Figure 1: Trade Ratio for Indonesia

Figure 1b: Export and Import of Indonesia with China

Figure 2: Trade Ratio for Korea

Figure 2b: Export and Import of Korea with China

Figure 3: Trade Ratio for the Philippines

Figure 3b: Export and Import of Philippines with China

18

Figure 4: Trade Ratio for Thailand

Figure 4b:Export and Import of Thailand with China 


\begin{abstract}
The study brings into light the evidence of a fundamental role of the Chinese renminbi in shaping the exchange rate behaviour of other major Asian currencies. The results obtained suggest that there is an additional dimension to the 'fear of appreciation' or 'fear of floating-in-reverse' behaviour, initially coined by Levy-yeyati and Sturzenegger (2007) with regard to these major Asian currencies. In particular, it is found that there is a greater degree of aversion to appreciation of these same Asian currencies, specifically, the Philippine peso and the Thailand baht against the renminbi than against the US dollar. This heightened fear of appreciation against the Chinese currency confirms that trade competition indeed matters in this part of the world and that the fear continues to play a central role in the exchange rate management behaviour of major Asian currencies. This is understandable as the rising role of China as a major trading hub in the region as well as globally, renders greater influence to the renminbi on the rest of the currencies in the region.
\end{abstract}

Key Words: $\quad$ Asymmetrical Exchange Rate Regime; East and Southeast Asia; Regime Switching Models.

JEL Classifications: E58; F31; F41 


\section{Introduction}

After three decades of spectacular growth, China surpassed Japan in the second quarter of 2010 to become the world's second-largest economy behind the United States. According to official figures from both Japan and China, the Japanese economy was valued at US\$1.28 trillion in the second quarter of 2010, slightly below China's US\$1.33 trillion economy (Barboza (2010)). Notwithstanding that growth has begun to moderate slightly, China's economy is still officially forecasted to expand by about 10 percent ---continuing a remarkable three-decade streak of double-digit growth.

In their study, Branson and Healy (2005) demonstrate that the structure of China's exports, both in terms of market and commodity circulation, is parallel to that of a number of Asian economies. They argue, therefore, that Asian economies should have the incentive to keep a close watch on renminbi fluctuations in managing their currencies in order to avoid any potential loss in competitiveness. Similarly, Shu, Chow and Chan (2007) claim that the renminbi has indeed started to figure more prominently in the currency baskets of the Asian economies, primarily due to competitive relationships between China and these economies in the global export markets. One such cursory evidence is the significant rise in the bivariate correlation between the renminbi and individual Asian currencies (Table $1)$.

The influences of the renminbi on Asian currencies have long been debated amongst policy makers and academics, but only a few recent works have explicitly demonstrated those impacts. One study carried out by Colavecchio and Funke (2007) investigate the spill-over effects from the renminbi to Asian currencies in the onshore and offshore forward markets. Similarly, Ho et al. (2005) noted that the renminbi non-deliverable forward rates had some bearing on the spot rates of the Asian currencies during the period of rising speculation on renminbi appreciation in 2003- 2004. Applying the Frankel and Wei (1994) framework, Shu, Chow and Chan (2007) claim that since July 2005, the fluctuations of the renminbi that are independent of those of the US dollar tend to lead to movements in the same direction in other Asian currencies.

Against this backdrop, our study examines the currencies of four East and Southeast Asian economies, namely the Indonesian rupiah, the Korean won, the Philippines peso and the Thailand baht. Immediately after the 1997 East Asian crisis, the monetary authorities of these economies announced their commitments to abandon their rigid soft-US dollar policies and let their currencies float more flexibly. Furthermore, to regain confidence in their domestic monetary policies, the central banks of these economies have officially adopted inflation targeting policy regimes. Intrinsically, the exchange rate is expected to move more flexibly under an inflation targeting policy.

The first primary contention to be dealt with in this paper is that while the adoption of the inflation targeting policy in these four Asian economies may lead to more flexible exchange rate movements, under various circumstances, it is however possible that the degree of flexibility is significantly higher on one side of the market. ${ }^{1}$ In other words, the monetary authorities of these four Asian economies can asymmetrically manage their exchange rates wherein they can allow for some

\footnotetext{
${ }^{1}$ See, for instance, Stigler et al (2009) for this various set of plausible reasons.
} 
currency depreciation while substantially limiting the extent of currency appreciation. For the lack of better alternatives, this exchange rate intervention behaviour has been coined by Levy-yeyati and Sturzenegger (2007) as 'fear of floating in reverse' or 'fear of appreciation'.

Past studies have looked into this issue of asymmetrical exchange rate behaviour across a number of Asian currencies. Ramachandran and Srinivasan (2007), for instance, employ a simple dummy variable to account for depreciations and appreciations. On the other hand, Srinivasan, Mahambare and Ramachandran (2008) explore a cubic loss function to account for possible asymmetric behaviour. The study of Stigler, Patnaik and Shah (2009) apply time series techniques in the context of structural change of the exchange rate regime. Furthermore, Pontines and Rajan (2010) similarly employs the cubic loss function of Srinivasan et al (2008) and tests the model across a broader set of emerging Asian economies that are known to operate a variety of managed floats viz., India, Indonesia, Korea, Philippines, Singapore and Thailand.

However, these previous studies' emphasis is in the context of an asymmetrical management of the Asian domestic currencies with respect to the US dollar. Hardly any of these earlier studies have considered the possible role of a 'third currency' that may in account for an asymmetrical exchange rate intervention behaviour. In particular, none has considered the plausible role of the Chinese renminbi in shaping exchange rate management of these Asian currencies, especially following the 2005 exchange rate policy reform in China. ${ }^{3}$ This then leads us to the second and related key policy concern to be assessed in this paper. In view of the alleged bias on one side of the market -- some domestic currency depreciation is allowed while substantially restraining the extent of domestic currency appreciation explicitly against the US dollar -- does this aversion to appreciation also extends and applies to their domestic currencies with respect to the Chinese renminbi? Given the nuances and the intricacies which entail from the emerging dominant role of the Chinese economy in Asia, in particular, and in the world, in general, this is a logical and interesting research question that is worth pursuing.

In our empirical work, the well-known class of regime switching model known as the Markov regime-switching is employed. Under this framework we treat asymmetry in exchange rate behaviour as being equivalent to evidence of persistence. Testing for the presence of persistence is then achieved via the comparison of transition probabilities across two different regimes. To the best of our knowledge, our paper is the only one thus far that employs such a technique in the context of flexible exchange rate

\footnotetext{
${ }^{2}$ Such asymmetry in exchange rate behaviour have been pointed out much earlier by Almekinders and Eijffinger (1996) when they find that during the post-Louvre period, US and German central banks have tried to counteract appreciations of their currency more strongly than depreciations.

${ }^{3}$ In July 2005, the People's Bank of China (PBC) announced its policy intention to set the value of renminbi with reference to a basket of foreign currencies, and to allow the currency to move more flexibly. The outcome was arguably a more measured and deliberate approach akin to a managed crawl whereby the currency was allowed to appreciate by around 20 percent against the dollar from 2005 to late 2008 .
} 
policies under inflation targeting regimes in East Asia. ${ }^{4}$

The rest of the paper is set out as follows. The empirical section is presented next which includes a discussion of the model specifications and econometric testing employed. The key empirical findings are analysed and highlighted in Section 3. In the following section, we present and assess bilateral trade patterns of the four Asian economies. The main objective of this section is to evaluate the test results presented in Section 3 and to further substantiate the analyses. A brief concluding section ends the paper.

\section{Empirical Approach}

We now turn to the empirical approach adopted in this paper. One widely used approach in estimating the weight or influence of a currency on another is the following Frankel and Wei (1994) framework formally expressed as:

$$
\Delta e_{j}=\alpha_{0}+\sum_{i=1}^{k} \alpha_{i} \Delta e_{i}
$$

In equation (1), $\left(e_{j}\right)$ and $\left(e_{i}\right)$ s are, respectively, exchange rate of the currency under study and those currencies that might influence it. A significant $\left(\alpha_{i}\right)$ would suggest that currency $(i)$ has an impact on $\left(e_{j}\right)$, and $\left(\alpha_{i}\right)$ is interpreted as the weight of currency $(i)$ in the currency basket. In their work, Shu, Chow and Chan (2007) applies this approach and claims that there is a clear rise in the importance of the renminbi in influencing other Asian currencies during the post July $2005 .^{5}$

Whilst the Frankel and Wei framework would be useful in revealing the weight or importance of the renminbi, the framework is not explicitly designed to convey any information on the degree of aversion to exchange rate management, either for currency appreciation or depreciation. For instance, the estimates of the $\left(e_{i}\right) \mathrm{s}$ in equation (1) are time-invariant coefficients and as such, cannot account for asymmetrical behaviour. Thus, this conventional approach will not address our primary question on the possibility of fear of appreciation in exchange rate behaviour of our four Asian currencies. The empirical approach adopted in this paper then takes the view that in order to test for the existence of fear or aversion to appreciations, one has to resort to a time-varying approach and one such suggested strategy is via a simple comparison of the estimated probabilities of remaining in the state or regime of depreciation as against that of the state or regime of appreciation.

In this regard, in order to circumvent the limitation of the Frankel and Wei framework, our study instead employs the Markov-regime switching approach. Earlier introduced to the time-series

\footnotetext{
${ }^{4}$ The paper that comes very close to our work is by Leon and Najarian (2005) which adopts a similar set of comprehensive tests but undertakes it in the context of deviations from PPP. In addition, Stigler et al (2009) also adopts threshold modeling procedures but uses the self-exciting threshold autoregressive (SETAR) process and the momentum threshold autoregressive model (MTAR) in approaching the issue of asymmetric exchange rate behaviour.

${ }^{5}$ The other Asian currencies in their study include the Hong Kong dollar, Indian rupee, Indonesian rupiah, Korean won, Malaysian ringgit, Philippines peso, Singapore dollar, New Taiwan dollar and Thai baht.
} 
econometric literature by Hamilton $(1988,1989)$, the general idea behind the Markov-regime switching is that the parameters of the autoregressive process may not be time-invariant, as assumed by linear models. More precisely, the parameters may be time-invariant as long as a particular regime prevails, but change once the regime changes.

Denoting $\Delta$ lnexr as the first difference of the log of the nominal exchange rate (defined as either the domestic currency per US dollar or the domestic currency per Chinese renminbi), we estimate a univariate regime switching model which can be written in the form:

$$
\Delta \ln \operatorname{exr}_{t}=\alpha\left(s_{t}\right)+\sum_{k=1}^{p} \alpha_{k}\left(s_{t}\right) \Delta \ln \operatorname{exr}_{t-k}+\sum\left(s_{t}\right) \varepsilon_{\Delta \ln e x r, t} \quad \varepsilon_{\Delta \operatorname{lnexr}, t} \sim N(0,1)
$$

where $s_{\mathrm{t}}$ is the unobservable regime, and $\mathcal{E}_{\mathrm{t}}$ is the innovation process with a regime-dependent variancecovariance matrix $\Sigma\left(s_{\mathrm{t}}\right)$. Maximum likelihood estimation of (2) yields the 'smoothed' probabilities, representing the ex-post inference about the system being in regime $i$ at year $t$. It is assumed that $s_{\mathrm{t}}$ follows an irreducible ergodic two-regime Markov process with the transition matrix $\mathbf{P}$ :

$$
\mathrm{P}=\left[\begin{array}{ll}
p_{11} & p_{12} \\
p_{21} & p_{22}
\end{array}\right]
$$

Constant transition probabilities $p_{\mathrm{ij}}$ are assumed:

$$
p_{i j}=\operatorname{Pr}\left(s_{t}=j \mid s_{t-1}=i\right), \quad \sum_{j=1}^{2} p_{i j}=1, \quad \forall i, j \in\{1,2\}
$$

The Markov-regime switching model employed here is well-suited to testing whether East Asian currencies exhibit aversion to appreciations because it yields these transition probabilities. Focusing on $p_{11}$ (the probability of remaining in the lower regime, i.e., regime 1, given that the process was in the lower regime at time $(t-1)$ ) and $p_{22}$ (the probability of remaining in the higher regime, i.e., regime 2 , given that the process was in the higher regime at time $(t-1)$ ), these transition probabilities can be utilised to test for the degree of asymmetrical exchange rate policy. If the probability of remaining in the upper regime is greater than that of remaining in the lower regime, it suggests an aversion of monetary authorities to currency appreciations. Or, more formally:

$$
\operatorname{Pr}\left(s_{t}=2 \mid s_{t-1}=2\right)>\operatorname{Pr}\left(s_{t}=1 \mid s_{t-1}=1\right)
$$

\section{Empirical Results}

Our estimation is based on monthly data for the period 2000:m1 -2006:m12 for four inflationtargeting emerging Asian economies of Indonesia, Korea, Philippines and Thailand. The sample period was chosen in view of the fact that the bulk of the reserves accumulation for these economies occurred during this period (i.e. post Asian crisis of 1997-98) as well as to steer clear of the substantial exchange rate instabilities experienced by these economies during the global financial crisis of 2007-2009. All nominal exchange rate data (domestic currency per US\$ and the domestic currency per Chinese renminbi) are obtained from the Pacific Exchange Rate Service (http://fx.sauder.ubc.ca). 
The starting point in the empirical analysis is to formally test the null hypothesis of no regime switching in the mean, the variance-covariance matrix, and the autoregressive coefficients against the alternative of regime switching. The null hypothesis is equivalent to a constant mean and autoregressive parameters, homoscedastic linear AR model. The Davies (1987) approach is employed for testing this hypothesis. As shown in the last row of Table 2, the null of no regime switching is rejected for all four East Asian currencies. On this basis, the estimated results of the nonlinear regime switching AR model wherein the first difference of the log of the nominal exchange rate defined as the domestic currency per US dollar are reported in Table 2. The results yields plausible estimates of the coefficients in both regimes 1 and 2 and for the most part, the coefficients are statistically significant at conventional levels.

The estimated results of the nonlinear regime switching AR model of the first difference of the $\log$ of the nominal exchange rate defined this time as the domestic currency per Chinese renminbi are reported in Table 3. Again, the regime switching AR is strongly preferred to the linear AR specification as presented in the last row of Table 3. Furthermore, the estimated results in Table 3 offer similar observations as compared to the estimated results of the nonlinear regime switching AR model using the domestic currency per US dollar as the definition of the nominal exchange rate (Table 1) - plausible estimated coefficients and for the most part statistically significant at conventional levels.

More importantly, the analysis of the standardised residuals emanating from the estimated nonlinear regime switching AR models as previously presented in Tables 2 and 3 provide evidence of no residual serial correlation in the residual series (Ljung-Box $Q$ test). There is also no evidence of conditional heteroscedasticity (ARCH-LM test) in any of the residual series (see Table 4). ${ }^{6}$ This provides further proof that the regime-switching dynamics adopted in this paper captures fairly well the nonlinearity and conditional heteroscedasticity in the respective nominal exchange rate series.

We now turn to the core results of this paper and examine the estimated transition probabilities as reported in Table 5. It is remarkably clear that for all of the four East Asian currencies considered, the probability of remaining in the upper regime $\left(p_{22}\right)$ is greater than that remaining in the lower regime $\left(p_{11}\right)$, suggesting an aversion to appreciation. This finding is true not just in the case of the nominal exchange rate being defined as the domestic currency per US dollar, but also applies as such in the case of the nominal rate being the domestic currency per Chinese renminbi.

More to the point, it is striking from the results that while the extent of this observed aversion to appreciation varies by degree amongst the four East Asian currencies per nominal exchange rate definitions, the extent of this observed bias on one side of the market also differs in terms of the two comparator base currencies. For instance, the degree of the observed aversion to appreciation in the case of the Indonesian rupiah and the Korean won are both indistinguishable, regardless of whether one looks at the US dollar as the base currency or the Chinese renminbi. In contrast, the cases of the Philippine peso

\footnotetext{
${ }^{6} \mathrm{~A}$ slight exception to this observation is the case of the nonlinear regime switching AR model estimated in the case of the Philippine peso using the domestic currency per Chinese renminbi as the definition of the nominal exchange rate wherein the null of no residual serial correlation is rejected at the $10 \%$ level of significance.
} 
and the Thailand baht exemplify a much greater aversion to appreciations when the Chinese renminbi is used as the comparator base currency.

\section{Recent Trends in Bilateral Trade Patterns and the Dominant Role of Mainland China}

Our empirical testing brings to light the evidence of a fundamental role of the Chinese renminbi in shaping the exchange rate management of the major Asian economies. The greater degree of aversion to appreciation of the Philippine peso and the Thailand baht against the renminbi than against the US dollar appears to suggest that there is an even more heightened fear of appreciation against the renminbi that is exemplified by the policy makers in these two countries during the period of observation. In view of this, we are led to conclude that the fear of appreciation against the Chinese renminbi, rather than the US dollar, contributed more to the asymmetrical exchange rate behaviour on the part of monetary authorities in the Philippines and Thailand. Likewise, given relatively identical degrees of aversion to appreciation of the Indonesian rupiah and the Korean won against the US dollar and the renminbi during the observed period, we also cannot rule out right-away the seeming underlying and extensive influence of the renminbi to an asymmetrical exchange rate behaviour on the part of monetary authorities in Indonesia and Korea.

How can we possibly explain such an influential role that the renminbi has on the Asian currencies? One of the frequently advanced factors behind the increasing influence of the Chinese renminbi is the rise of China as a major trading partner of countries around the globe, including that of the four Asian economies in our study. A simple calculation of trade ratios for all four Asian economies in terms of their bilateral trade patterns with China, US and Japan consistently reveal the fast and emerging dominant role of China in the region (Figures 1-4). ${ }^{7}$ The steep increase in total trade with China started to be noticeable in the immediate aftermath of the 1997 East Asian crisis in all four Asian economies.

In addition, we also find that these four Asian economies experience distinct overall trade balance positions against China (Figures 1b-4b). On the one hand, Indonesia and Korea have persistently been successful in maintaining healthy trade surpluses in their overall trade with China since the mid-1990s. In stark contrast, Thailand, throughout the 1990s and until the period of observation, has persistently suffered a trade deficit with China, and its bilateral trade deficit seems to be widening beginning in 2003 and onwards. Meanwhile, with the recent steep rise in its exports of goods to China, the Philippines only started to record a trade surplus with China in 2003 and from 2005 onwards, after over a decade of sustained bilateral trade deficits with China. In light of these presented stylised facts, we can reasonably surmise that out of the four Asian economies examined, a country that either suffers a persistently bilateral trade deficit with China (Thailand) or a country that experiences less sustained bilateral trade

\footnotetext{
${ }^{7}$ The calculation of the trade ratio proceeds as follows. We take the ratio of total trade (exports plus imports) with China and total trade with that of the US and Japan, respectively. In the case of Indonesia, for instance, the ratio of total bilateral exports and imports of Indonesia with China against the total bilateral exports and imports of Indonesia with the US is calculated. We also do this for the ratio of total bilateral exports and imports of Indonesia with China against the total bilateral exports and imports of Indonesia with Japan. An increasing ratio, therefore, suggest the relative increasing role of China in the bilateral trade patterns of the four Asian economies, and a diminishing one for both the US and Japan.
} 
surpluses with China (Philippines) is more likely to exhibit or display a greater aversion to appreciation against the Chinese renminbi. This assertion is simply in conjunction with the argument that trade competition matters in this part of the world and definitely continues to play a central role in the exchange rate management behaviour of the four major Asian economies examined in this paper.

\section{Conclusion}

Despite the full adoption of inflation targeting policy as their monetary policy framework, we assert that there are still significant concerns in the four Asian economies examined in this paper, namely, Indonesia, Korea, Philippines and Thailand, of allowing market forces to completely determine their exchange rates. To be more specific, these Asian economies continue to be characterised by a greater aversion towards appreciation, or more commonly known as 'fear of appreciation'. This finding confirms the recent evidence obtained by the related work of Pontines and Rajan (2010) for these same set of Asian economies. Our study, however, goes one step further by bringing into light the vital role of the Chinese renminbi in shaping the exchange rate behaviour of these same four major Asian currencies. Whereas, some of the previous studies continue to underscore the return of the soft US dollar pegging in Asia postcrisis, ${ }^{8}$ our findings indicate that that there is a greater dimension to this story - the heightened fear of appreciation against the renminbi than against the US dollar, and much more so in the cases of the Philippine peso and the Thailand baht. This is understandable as the rising role of China as a major trading hub in the region and globally has clearly contributed to the significant influence of the renminbi on currencies in the region.

\footnotetext{
${ }^{8}$ See, for instance, McKinnon and Schnabl (2004).
} 


\section{References}

Almekinders, G.J. and Eijjfinger, S.C.W., (1996), "A Friction Model of Daily Bundesbank and Federal Reserve Bank intervention”, Journal of Banking and Finance, Vol. 20(8), pp. 1365-1380.

Barboza, D., (2010), China's Economy Overtakes Japan', International Herald Tribune, Tuesday, August 17.

Branson, W.H. and Healy, C.N., (2005), "Monetary and Exchange Rate Policy Coordination in ASEAN+1," NBER Working Paper, No. 11713.

Colavecchio, R. and Funke, M., (2007), "Volatility Dependence Across Asia-Pacific On-shore and Offshore U.S. Dollar Future Markets," Hamburg University, Mimeo.

Frankel, J.A. and Wei, S., (1994), "Yen Block or Dollar Blocak? Exchange rate Policies of the East Asian Economies," in Ito, T. and A. Krueger (eds), Macroeconomic Linkage: Savings, Exchange Rates, and Capital Flows, Chicago: University of Chicago Press, pp.295-333.

Leon, H. and Najarian, S., (2005), "Asymmetric Adjustment and Nonlinear Dynamics in Real Exchange Rates", International Journal of Finance and Economics 10(1), pp. 15-39.

Levy-Yeyati, E. and Sturzenegger, F., (2007), "Fear of Floating in Reverse: Exchange Rate Policy in the 2000s", Mimeo.

Mckinnon, R. and Schnabl, G., (2004), "The Return to Soft Dollar Pegging in East Asia? Mitigating Conflicted Virtue", International Finance, pp. 169-202.

Pontines, V. and Rajan, R., (2010), "Foreign Exchange Market Intervention and Reserve Accumulation in East Asia: Is there Evidence of 'Fear of Appreciation?", Mimeo.

Ramachandran, M and Srinivasan, N., (2007), "Asymmetric Exchange Rate Intervention and International Reserve Accumulation in India”, Economics Letters, Vol. 94(2), pp. 259-265.

Shu, C., Chow, N. and Chan, J., (2007), "Impact of the Renminbi Exchange Rate on Asian Currencies", China Economic Issues, Number 3, June.

Srinivasan, N., Mahambare, V. and Ramachandran, M., (2008), "Preference Asymmetry and International Reserve Accretion in India," Applied Economics Letters, pp.1-14.

Stigler, M., Patnaik, I. and Shah, A., (2009), “Asymmetries in Central Bank Intervention,” Mimeo. 
Table 1

Correlation between the Renminbi and Selected East and Southeast Asian Currencies

\begin{tabular}{|l|c|c|}
\hline & $\begin{array}{c}\text { Before reform } \\
(\text { Jan 5, 1999 - Jul 20, 2005) }\end{array}$ & $\begin{array}{c}\text { After reform } \\
\text { (Jul 21, 2005 - Apr 2, 2007) }\end{array}$ \\
\hline Indonesian rupiah & -0.436 & 0.625 \\
\hline Korean won & -0.040 & 0.764 \\
\hline Malaysian ringgit & -0.186 & 0.927 \\
\hline Philippine peso & -0.730 & 0.890 \\
\hline Singapore dollar & -0.083 & 0.893 \\
\hline Thai baht & -0.391 & 0.955 \\
\hline
\end{tabular}

Source: Shu, Chow and Chan (2007). 
Table 2

Estimation Results for Regime Switching Models of East Asian Currencies per US\$

\begin{tabular}{lcccc}
\hline & $\begin{array}{c}\text { Indonesian } \\
\text { rupiah }\end{array}$ & $\begin{array}{c}\text { Korean } \\
\text { won }\end{array}$ & $\begin{array}{c}\text { Philippine } \\
\text { Peso }\end{array}$ & $\begin{array}{c}\text { Thailand } \\
\text { Baht }\end{array}$ \\
\hline \multicolumn{5}{c}{ Regime 1} \\
& & & \\
intercept & $-0.000(0.015)$ & $-0.002(0.002)$ & $-0.003(0.004)$ & $-0.002(0.001)^{* * *}$ \\
$(\Delta \ln \text { exr })_{t-1}$ & $4.339(0.521)^{* * *}$ & $-0.333(0.169)^{* *}$ & $-0.408(0.193)^{* * *}$ & $0.167(0.064)^{* * *}$ \\
$(\Delta \ln \text { exr })_{t-2}$ & $0.569(0.198)^{* * *}$ & & $0.733(0.239)^{* * *}$ & $-0.529(0.068)^{* * *}$ \\
$(\Delta \ln \text { exr })_{t-3}$ & & & $-0.520(0.223)^{* * *}$ & $0.495(0.068)^{* * *}$ \\
$(\Delta \ln \text { exr })_{t-4}$ & & & $-0.277(0.142)^{* *}$ & \\
$(\Delta \ln \text { exr })_{t-5}$ & & & $-0.426(0.240)^{*}$ & \\
$(\Delta \ln \text { exr })_{t-6}$ & & & $0.078(0.213)$ &
\end{tabular}

Regime 2

$\begin{array}{lcccc}\text { intercept } & 0.002(0.003) & -0.002(0.002) & -0.000(0.003) & -0.002(0.001)^{* * *} \\ (\Delta \ln \text { exr })_{t-1} & 0.035(0.092) & 0.631(0.209)^{* * *} & 0.562(0.139)^{* * *} & 0.442(0.147)^{* * *} \\ (\Delta \ln \text { exr })_{t-2} & 0.038(0.145) & & -0.233(0.142) & 0.097(0.156) \\ (\Delta \ln \text { exr })_{t-3} & & 0.360(0.095)^{* * *} & -0.047(0.154) \\ (\Delta \ln \text { exr })_{t-4} & & 0.117(0.265) & \\ (\Delta \ln \text { exr })_{t-5} & & 0.008(0.121) & \\ (\Delta \ln \text { exr })_{t-6} & & 0.090(0.114) & \end{array}$

Linearity test

[0.00]

[0.00]

[0.00]

[0.00]

Numbers in parentheses and square brackets are standard errors and $p$-values, respectively.

Significancelevels: $* 10 \%, * * 5 \%$, ***1\%. 
Table 3

Estimation Results for Regime Switching Models of East Asian Currencies per Renminbi

\begin{tabular}{|c|c|c|c|c|}
\hline & $\begin{array}{l}\text { Indonesian } \\
\text { rupiah }\end{array}$ & $\begin{array}{c}\text { Korean } \\
\text { won }\end{array}$ & $\begin{array}{c}\text { Philippine } \\
\text { peso }\end{array}$ & $\begin{array}{c}\text { Thailand } \\
\text { Baht }\end{array}$ \\
\hline \multicolumn{5}{|c|}{ Regime 1} \\
\hline intercept & $-0.000(0.007)$ & $-0.000(0.000)$ & $-0.009(0.003)$ & $0.000(0.000)$ \\
\hline$(\Delta \ln e x r)_{t-1}$ & $4.346(0.535)^{* * *}$ & $-0.153(0.131)$ & $-0.514(0.184)^{* *}$ & $0.094(0.038)^{* *}$ \\
\hline$(\Delta \ln e x r)_{t-2}$ & $0.568(0.198)^{* * *}$ & $-0.244(0.140)^{*}$ & & $-0.142(0.044) * * *$ \\
\hline \multicolumn{5}{|c|}{ Regime 2} \\
\hline intercept & $0.001(0.002)$ & $-0.000(0.000)$ & $0.002(0.001)^{* *}$ & $0.000(0.00)$ \\
\hline$(\Delta \ln e x r)_{t-1}$ & $0.055(0.191)$ & $0.601(0.174)^{* * *}$ & $0.467(0.112)^{* * *}$ & $0.513(0.142)^{* * *}$ \\
\hline$(\Delta \ln e x r)_{t-2}$ & $-0.002(0.457)$ & $0.161(0.171)$ & & $0.045(0.129)$ \\
\hline Linearity test & {$[0.00]$} & {$[0.01]$} & {$[0.00]$} & {$[0.00]$} \\
\hline
\end{tabular}


Table 4

Diagnostic Test Results

\begin{tabular}{ccccc}
\hline & $\begin{array}{c}\text { Indonesian } \\
\text { rupiah }\end{array}$ & $\begin{array}{c}\text { Korean } \\
\text { won }\end{array}$ & $\begin{array}{c}\text { Philippine } \\
\text { peso }\end{array}$ & $\begin{array}{c}\text { Thailand } \\
\text { baht }\end{array}$ \\
\hline \multicolumn{5}{c}{ Per USD } \\
Ljung-Box $Q$ & {$[0.63]$} & {$[0.51]$} & {$[0.75]$} & {$[0.35]$} \\
ARCH-LM(8) & {$[0.69]$} & {$[0.21]$} & {$[0.73]$} & {$[0.64]$} \\
& & & & \\
per remninbi & & \\
Ljung-Box $Q$ & {$[0.88]$} & {$[0.55]$} & {$[0.06]$} & {$[0.25]$} \\
ARCH-LM(8) & {$[0.52]$} & {$[0.22]$} & {$[0.11]$} & {$[0.95]$} \\
\hline Numbers in square brackets arep-values.
\end{tabular}

Table 5

Transition Probabilities

\begin{tabular}{ccccc}
\hline & \multicolumn{2}{c}{ per USD } & \multicolumn{2}{c}{ per remninbi } \\
& $p_{11}$ & $p_{22}$ & $p_{11}$ & $p_{22}$ \\
\hline & & & & \\
Indonesian rupiah & 0.0245 & 0.9268 & 0.0194 & 0.9322 \\
Korean won & 0.3896 & 0.5765 & 0.3730 & 0.5763 \\
Philippine peso & 0.1988 & 0.6065 & 0.2570 & 0.9308 \\
Thailand baht & 0.6014 & 0.8524 & 0.0336 & 0.7832 \\
\hline
\end{tabular}


Figure 1

Trade Ratio for Indonesia

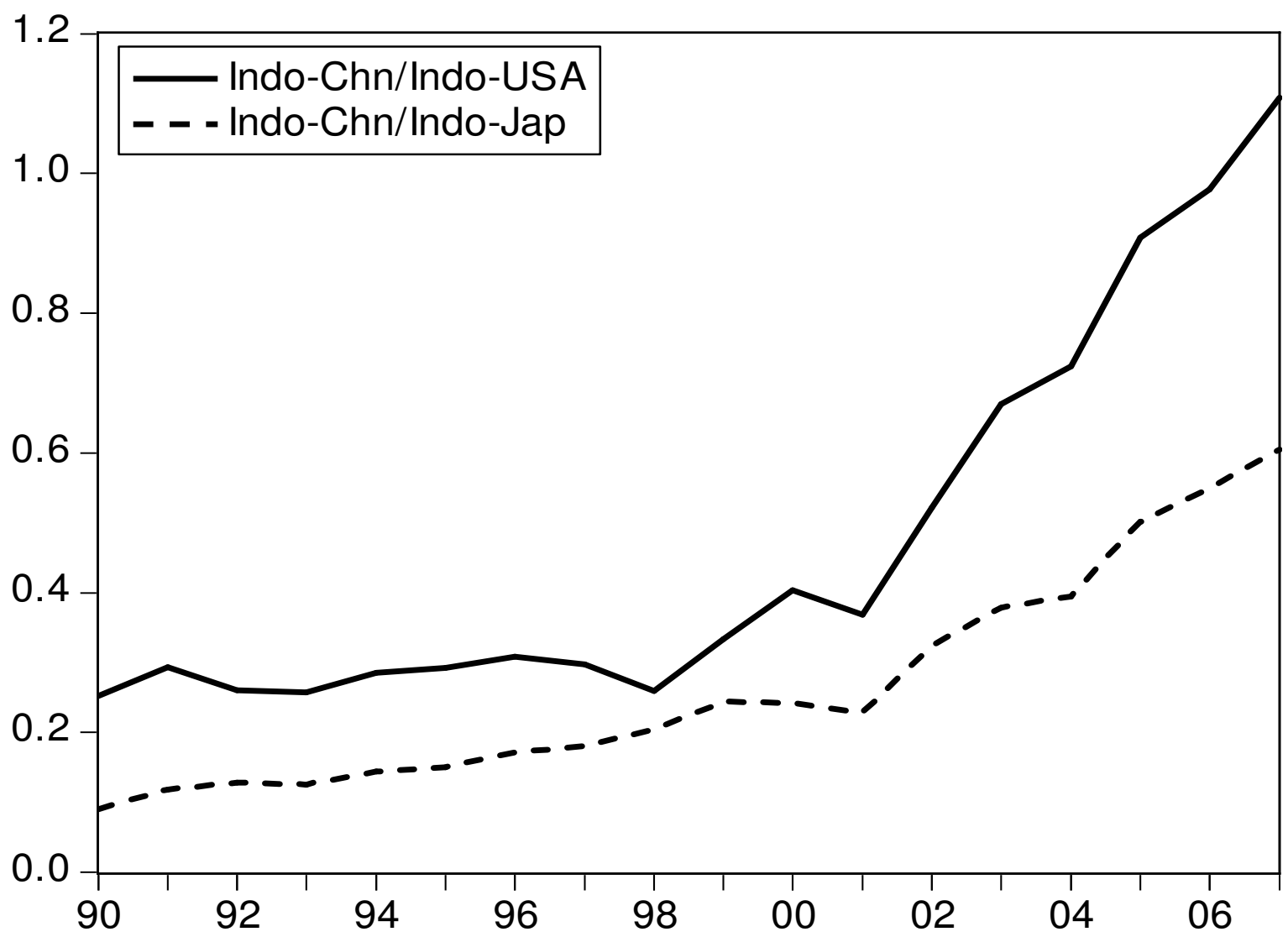

Note: a). Indo-Jap: total exports and imports between Indonesia and Japan.

b). Indo-USA: total exports and imports between Indonesia and USA.

c). Indo-Chn: total exports and imports between Indonesia and the People Republic of China.

Source: Authors' Computations and IMF Direction of Trade Statistics 
Figure 1b

Export and Import of Indonesia with China

(in million US dollars )

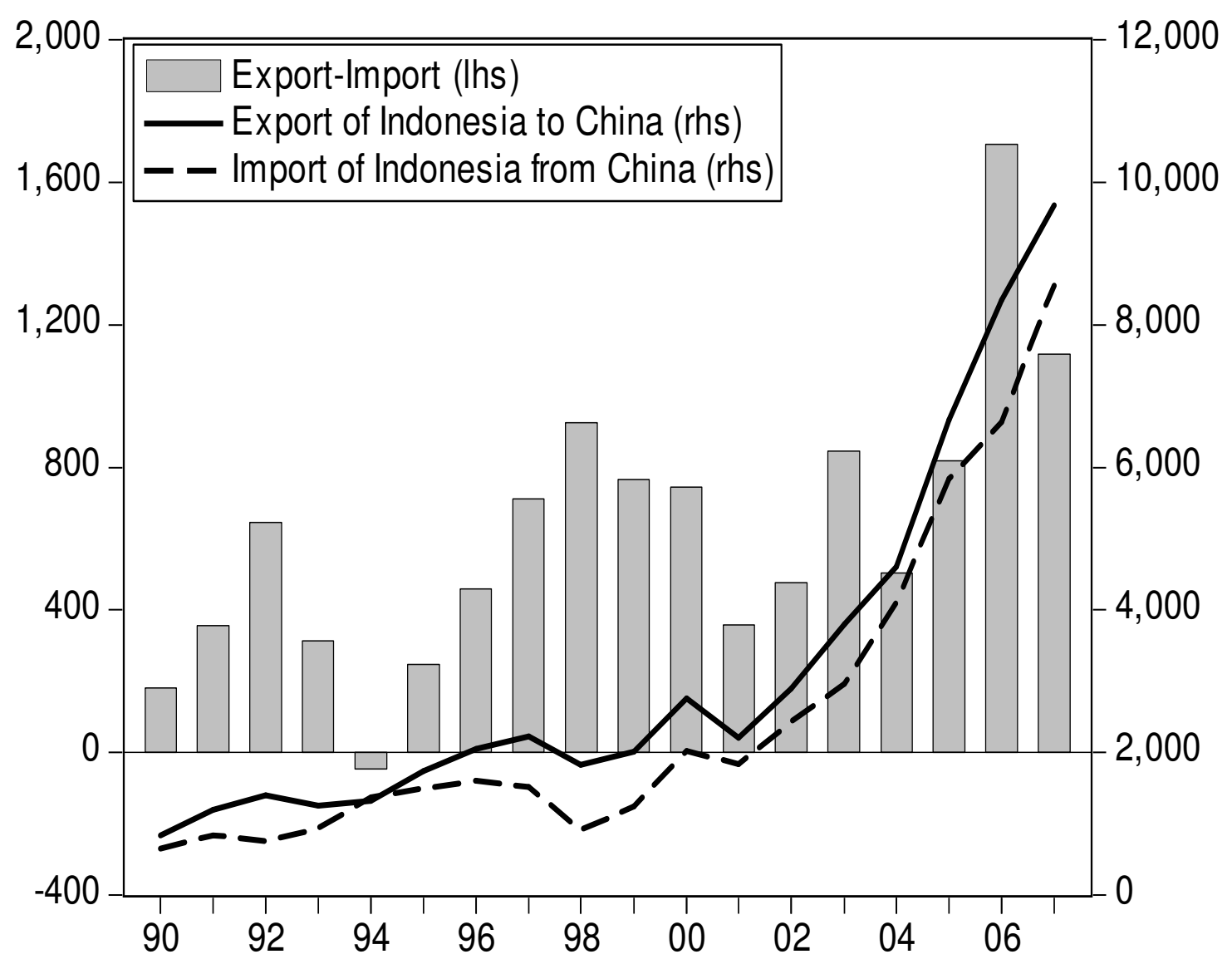

Source: IMF Direction of Trade Statistics. 
Figure 2

Trade Ratio for Korea

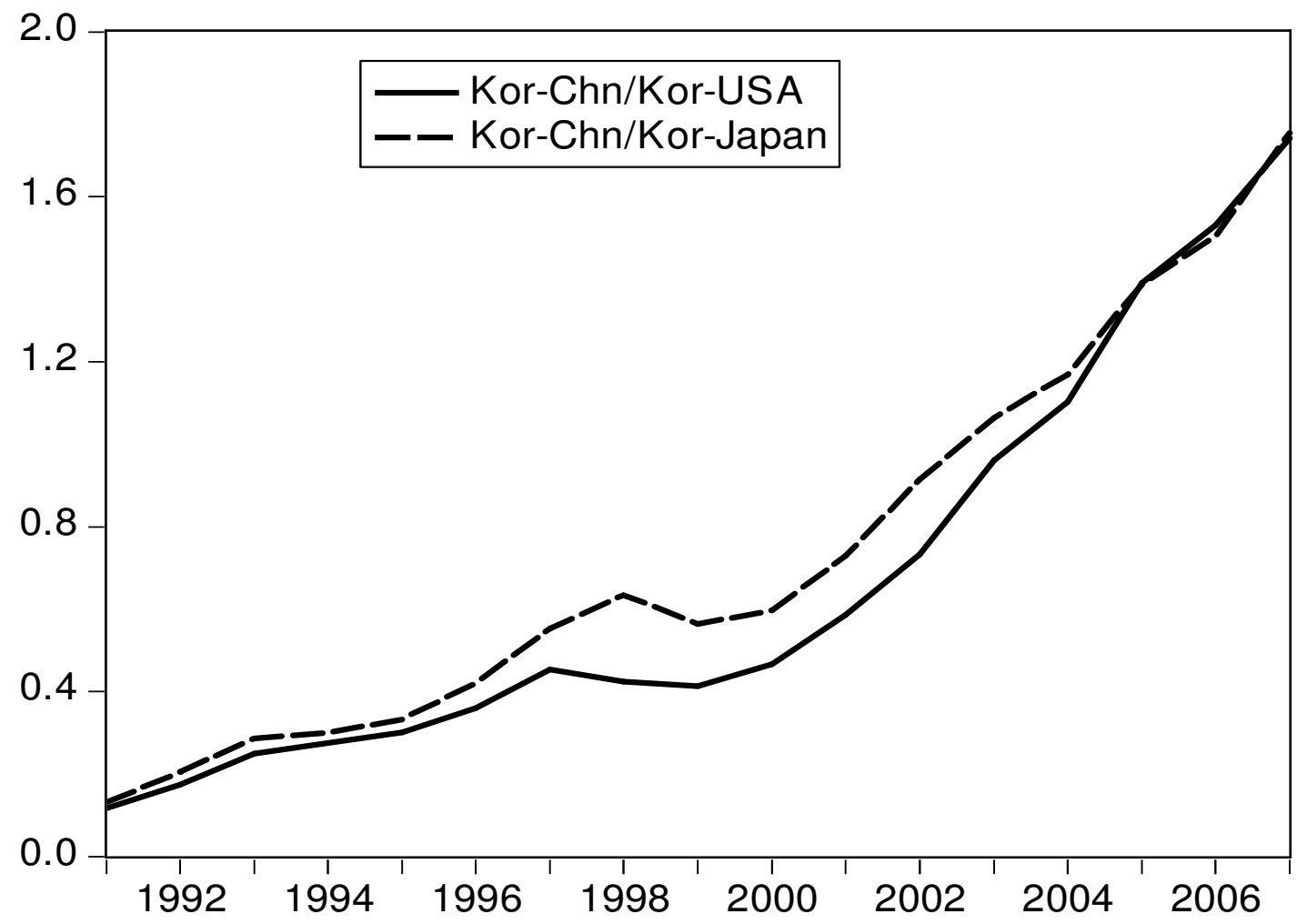

Note: a). Kor-Japan: total exports and imports between Korea and Japan.

b). Kor-USA: total exports and imports between Korea and USA.

c). Kor-Chn: total exports and imports between Korea and the People Republic of China.

Source: Authors' Computations and IMF Direction of Trade Statistics 
Figure 2b

Export and Import of Korea with China

(in million US dollars)

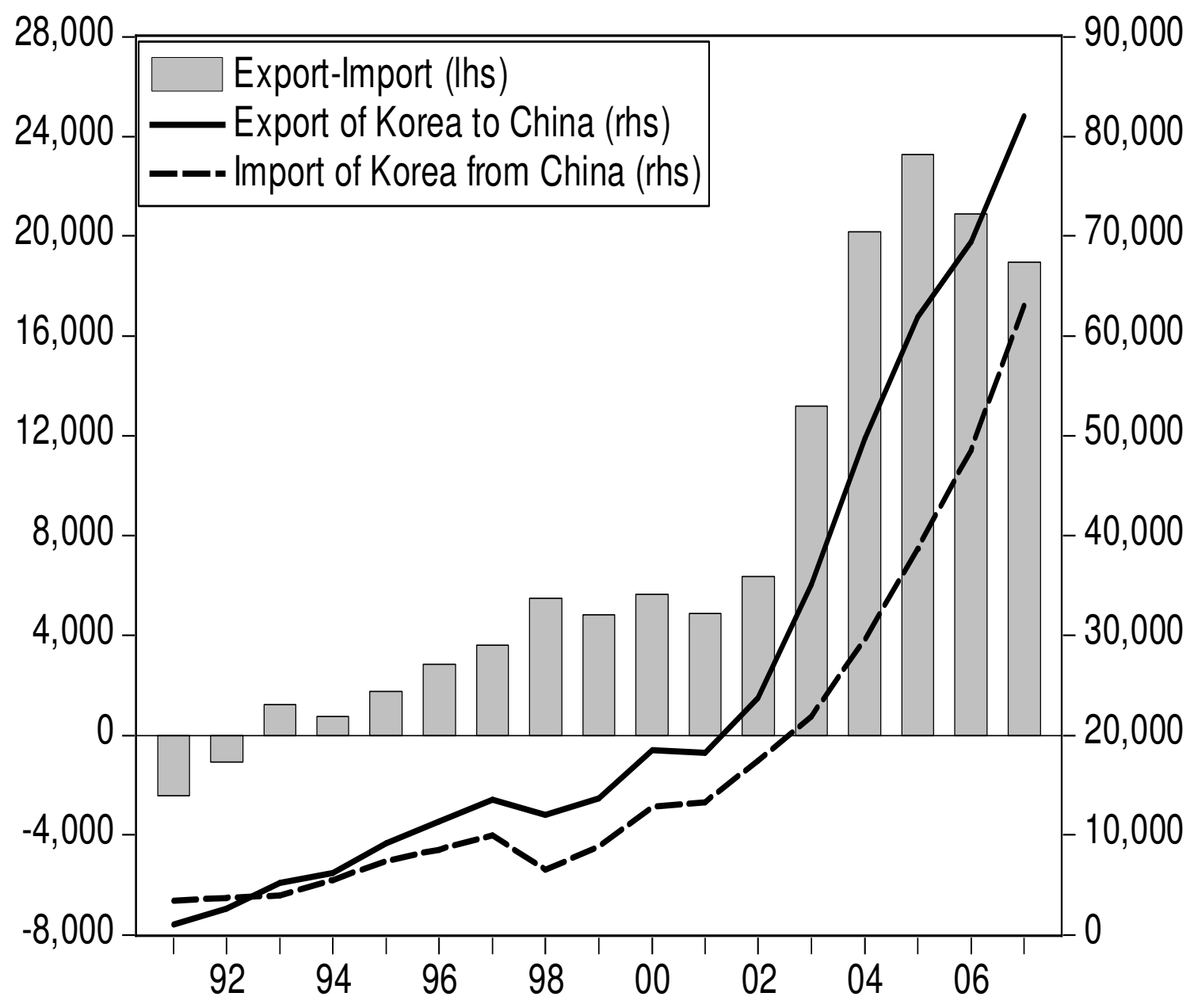

Source: IMF Direction of Trade Statistics. 
Figure 3

Trade Ratio for the Philippines

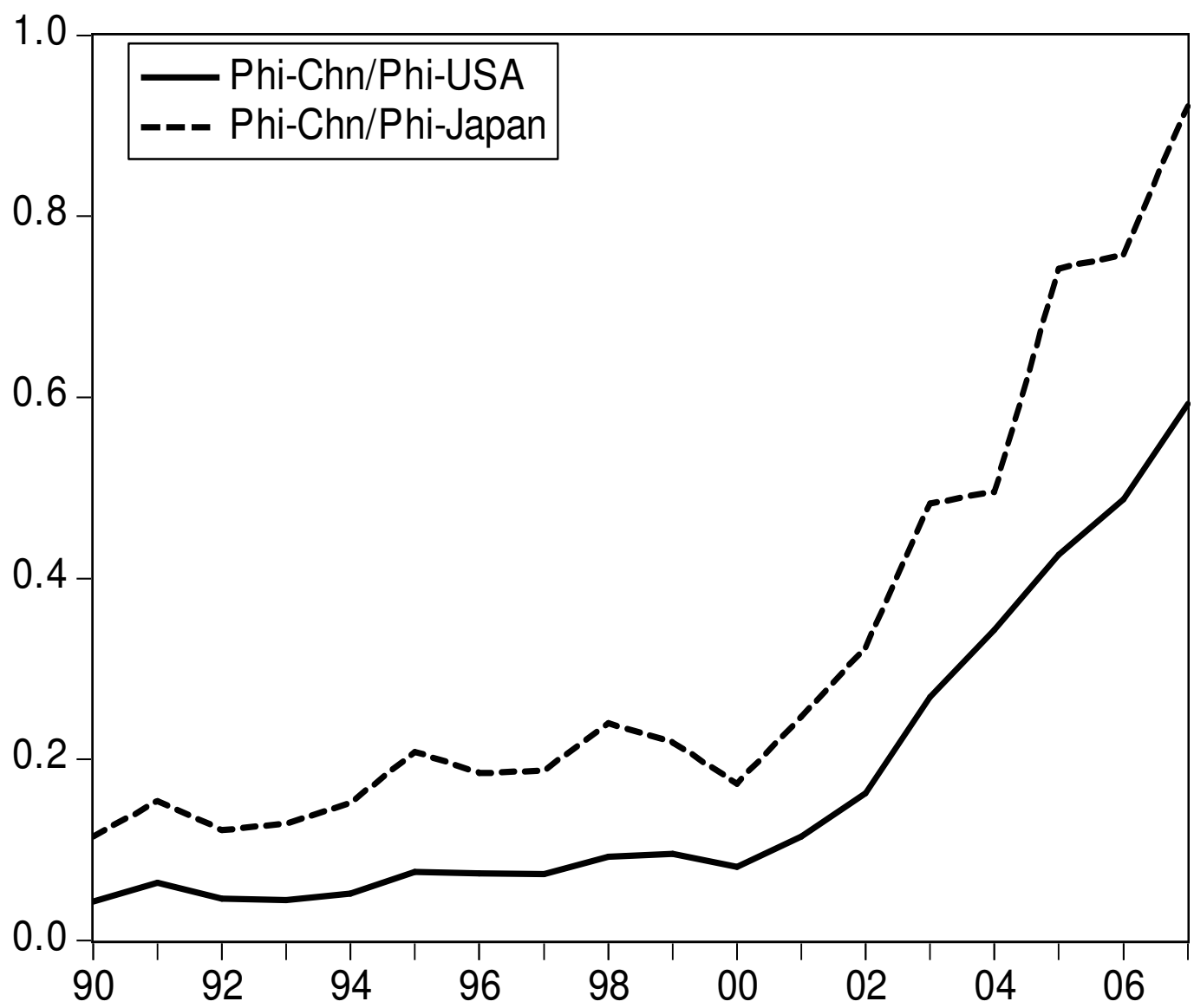

Note: a). Phi-Japan: total exports and imports between Philippines and Japan.

b). Phi-USA: total exports and imports between Philippines and USA.

c). Phi-Chn: total exports and imports between Philippines and the People Republic of China.

Source: Authors' Computations and IMF Direction of Trade Statistics 
Figure 3b

Export and Import of Philippines with China

(in million US dollars )

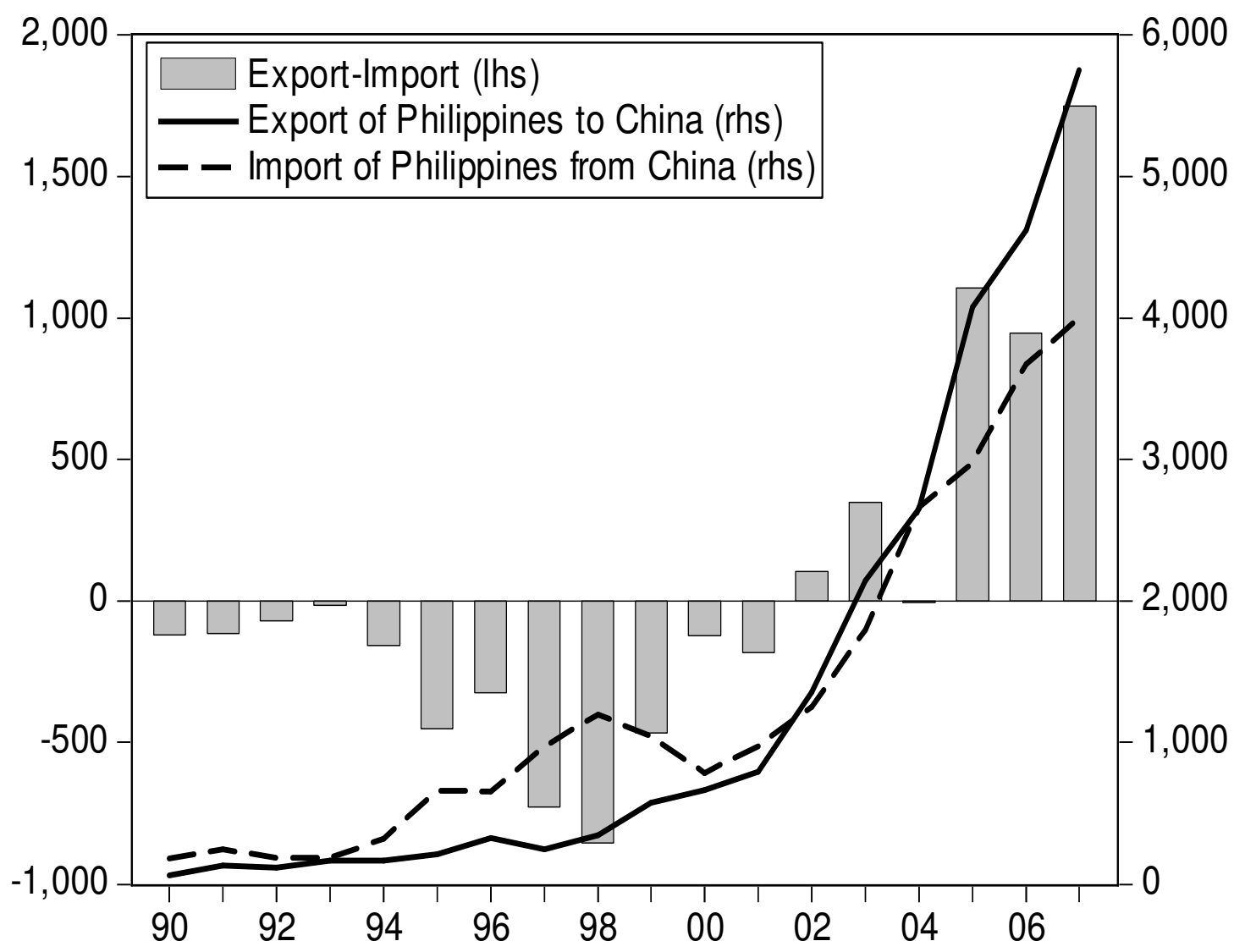

Source: IMF Direction of Trade Statistics. 
Figure 4

Trade Ratio for Thailand

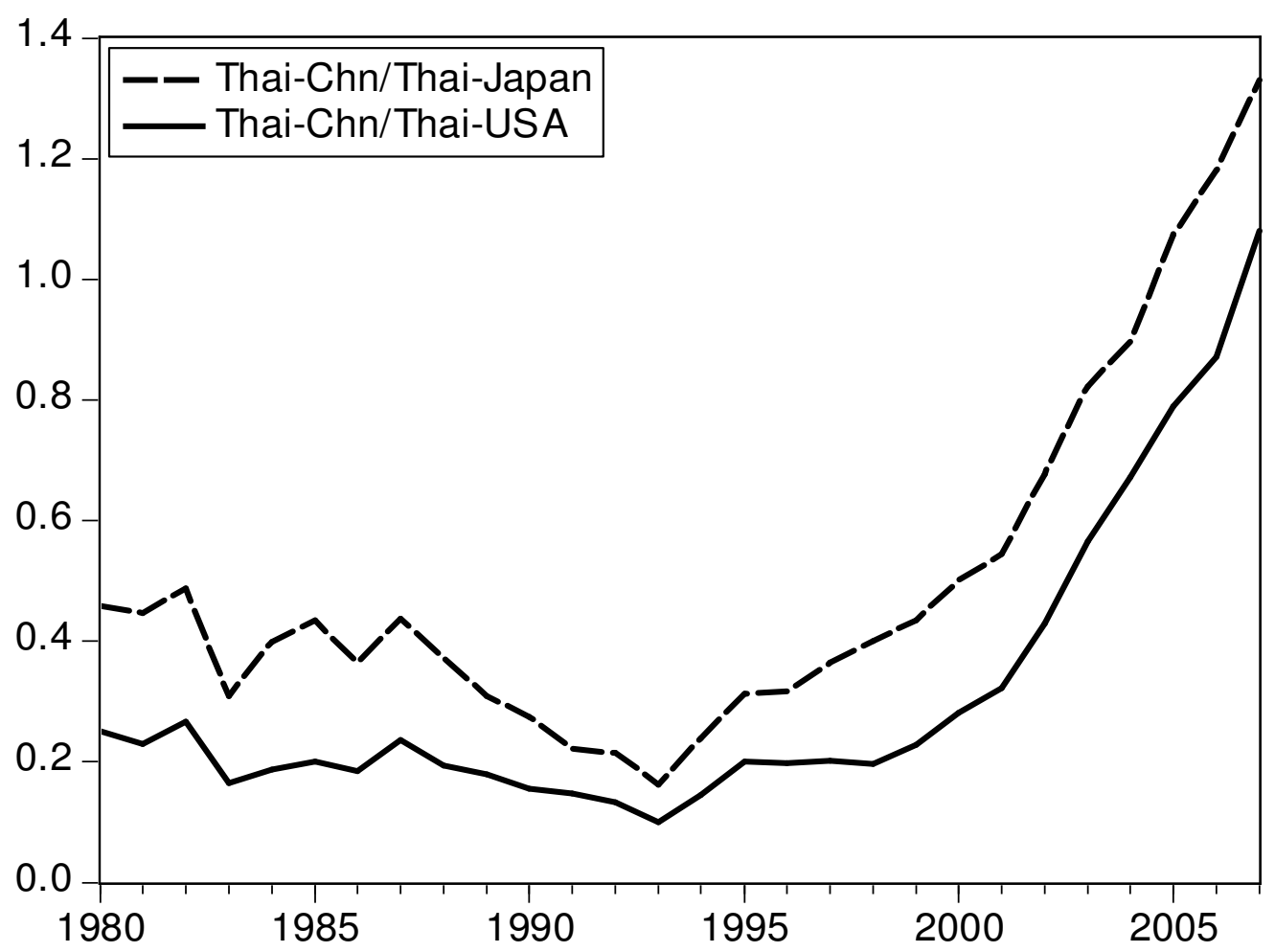

Note: a). Thai-Japan: total exports and imports between Thailand and Japan.

b). Thai-USA: total exports and imports between Thailand and USA.

c). Thai-Chn: total exports and imports between Thailand and the People Republic of China.

Source: Authors' Computations and IMF Direction of Trade Statistics 
Figure 4b

Export and Import of Thailand with China

(in million US dollars )

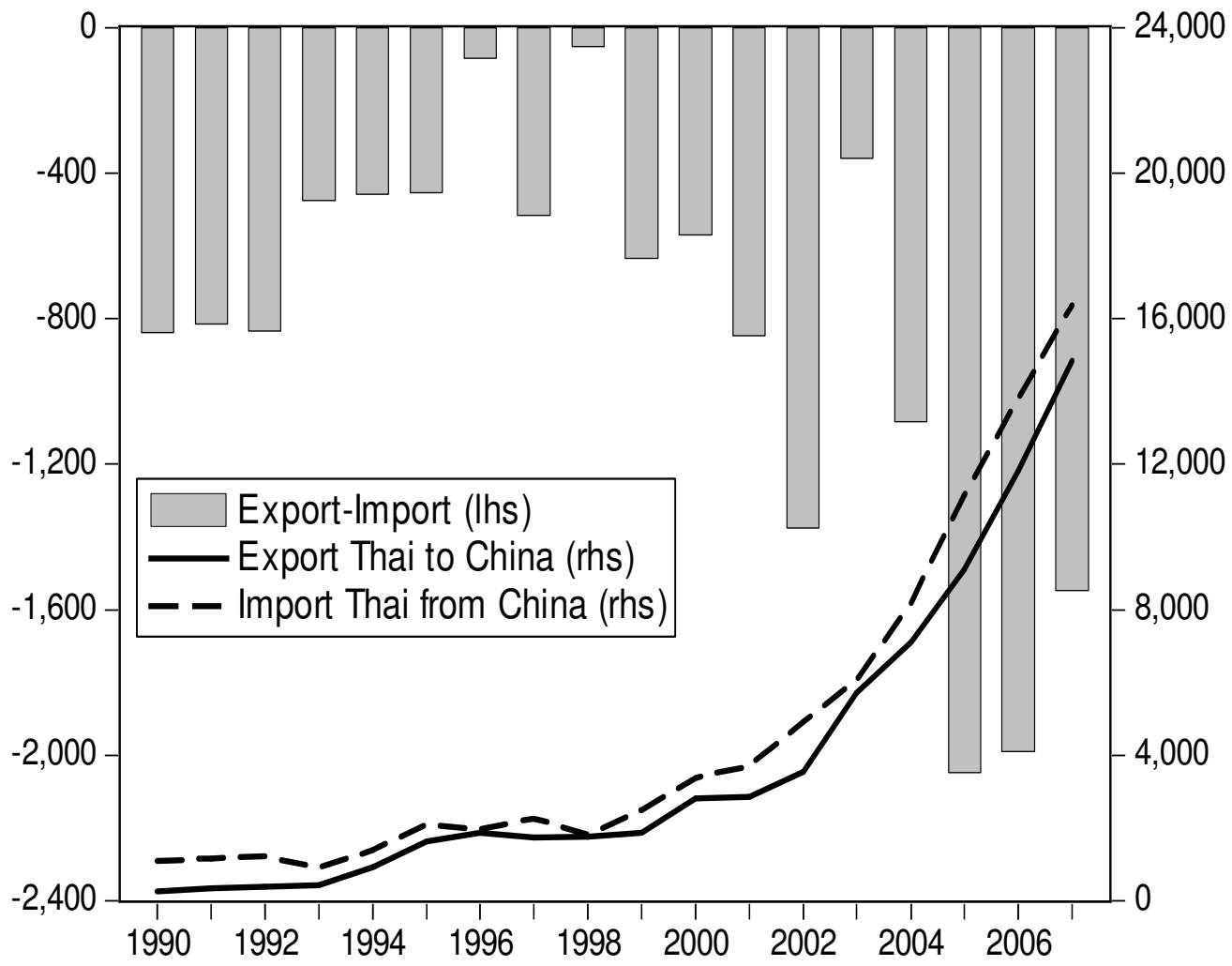

Source: IMF Direction of Trade Statistics. 